脳卒中診療体制のパラダイムシフト

宮本 享, 山田 清文

京都大学大学院医学研究科脳神経外科

\title{
Paradigm Shift in the Stroke Medical Care System
}

\author{
Susumu Miyamoto, M.D., Ph.D., and Kiyofumi Yamada, M.D. \\ Department of Neurosurgery, Kyoto University Graduate School of Medicine
}

Advances in mechanical thrombectomy have been rapidly progressing in medical treatment systems for acute ischemic stroke. Based on the 5-year plan for stopping CVD published in 2016, the Japan Stroke Society certified 975 centers in Japan as primary stroke centers for uniform iv t-PA therapy for $24 \mathrm{~h} /$ day, every day. Linking the 5 -year plan with a plan for promoting cardiovascular diseases will facilitate uniform primary care for stroke and adoption of advanced medical care.

(Received September 28, 2020 ; accepted October 7, 2020)

Key words : five-year plan for stop CVD, acute ischemic stroke, primary stroke center

Jpn J Neurosurg（Tokyo） $30: 194-198,2021$

\section{はじめに}

2015 年以後急性期脳虚血に対する機械的血栓回収療 法の有効性に関するエビデンスが続々と報告され, 脳卒 中診療体制は大きく変貌しつつある。2016 年 12 月に日 本脳卒中学会が日本循環器学会とともに発表した「脳卒 中と循環器病克服 5 力年計画」は脳卒中診療体制を整備 していくうえでの将来設計図となった。そして 2018 年 12 月に「健康寿命の延伸等を図るための脳卒中, 心臟病 その他の循環器病に係る対策に関する基本法」(以下「循 環器病対策基本法」) が成立したことにより, 諸整備がさ らに加速している1).

本稿では本邦における脳卒中の診療体制がどのように 整備されつつあるかについて紹介する.

\section{脳卒中をめぐる最近の動き}

日本脳卒中学会と日本循環器学会は 2016 年 12 月に 「脳卒中と循環器病克服 5 力年計画」を発表した。本計画 では「脳卒中と循環器病の年齢調整死亡率を 5 年間で $5 \%$ 減少させる」,「健康寿命を延伸させる」という 2 つの大 目標を設定し，「脳卒中」「心不全」「血管病（急性心筋梗 塞, 急性大動脈解離, 大動脈瘤破裂, 未梢動脈疾患)」の 3 疾患を対象に，(1)「人材の育成」，(2)「医療体制の充 実」, (3)「登録事業の促進」, (4)「予防・国民への啓発」, (5)「臨床・基礎研究の強化」の 5 事業を推進してきた $(\text { Fig. 1 })^{2)}$. 本計画の「医療体制の充実」の中では, rt-PA 静注療法を 24 時間 365 日施行可能 (以下 $24 / 7$ ) な「1次 脳卒中センター」(primary stroke center：PSC)，血管内 治療や高度の外科治療のできる「包括的脳卒中センター」 の整備が提案された。 5 力年計画に脳卒中センターの整 備計画が書き込まれたことは, 結果的には脳卒中診療体

\footnotetext{
連絡先：宮本 享, 干 606-8507 京都市左京区聖護院川原町 54 京都大学大学院医学研究科脳神経外科

Address reprint requests to: Susumu Miyamoto, M.D., Ph.D., Department of Neurosurgery, Kyoto University Graduate School of Medicine, 54 Kawaharacho, Shogoin, Sakyo-ku, Kyoto-shi, Kyoto 606-8507, Japan
} 


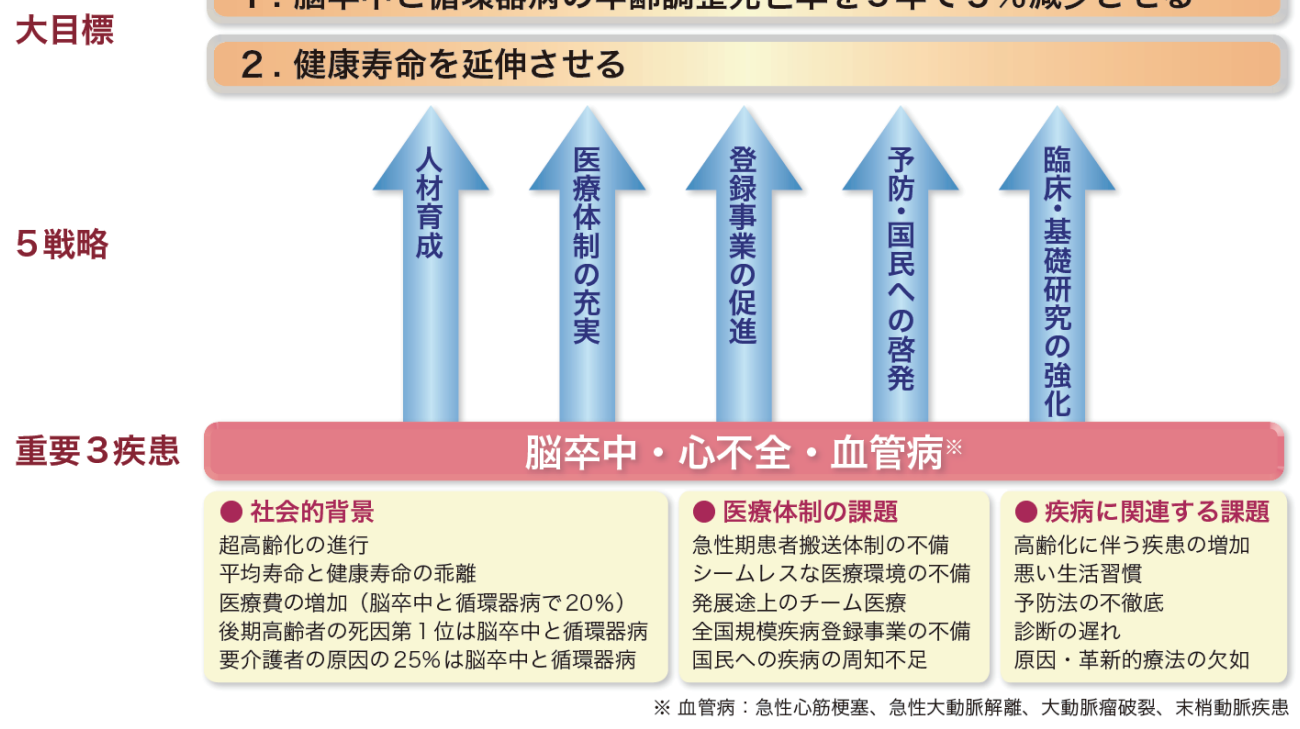

Fig. 1 Five-year plan for stop CVD ${ }^{2)}$

Table1 Standards for certifying PSC ${ }^{4)}$

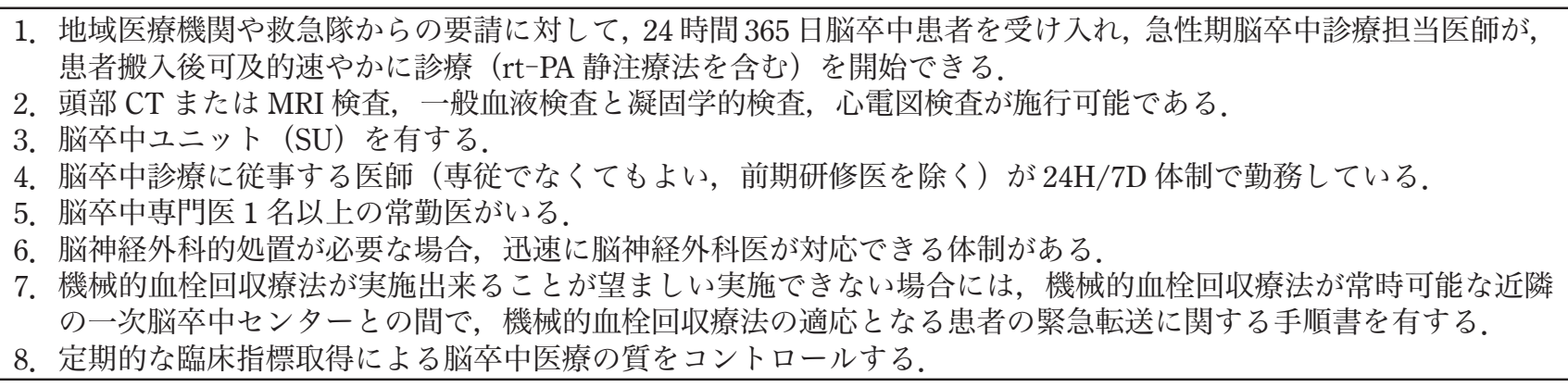

制を整備していくうえでの大きな転機となった。さらに その翌年 2017 年 7 月に公表された厚生労働省（厚労省） の「脳卒中，心臟病その他の循環器病に係る診療提供体 制の在り方に関する検討会」が発表した報告書において も同様の整備の必要性が示されるとともに，「脳卒中の 急性期診療提供のための施設間ネットワークのイメー ジ」として, 「医療資源がそしい地域」と「医療資源が豊 富な地域」に分けて計画を行うことが提案されている.

日本脳卒中学会は 2017 年 3 月に, 5 力年計画実現化委 員会を設置し，5事業のうち主に「医療体制の充実」と 「登録事業の促進」に傾注して整備を進めることになっ た.

\section{医療体制の充実}

上記の方針に基づき，日本脳卒中学会では 2019 年に
PSC の認定を行うべく，施設認定基準を定めた（Table 1) ${ }^{3)}$.

このように脳卒中と循環器病克服 5 力年計画の実現に 向けて整備が進む中，2018 年 12 月に循環器病対策基本 法が成立した。本法はもともと日本脳卒中協会が中心と なり脳卒中対策基本法の立法化を目指してきた動きが衆 議院の解散などの糿余曲折を経て，脳卒中と心臟血管病 の双方を扱う「脳卒中・循環器病対策基本法 (仮称)」と して成立したものであるが，現在の厚労省行政では脳卒 中は循環器病に含まれるため, 略称としては循環器病対 策基本法となっている.

循環器病対策基本法は成立から 1 年後の 2019 年 12 月 に施行され，それに基づき，2020年 1 月に厚労省に循環 器病対策推進協議会が設置され，7月に循環器病対策推 進基本計画案が策定され，パブリックコメントを経て, 9 月に閣議決定される予定となっている. そして, 同基 


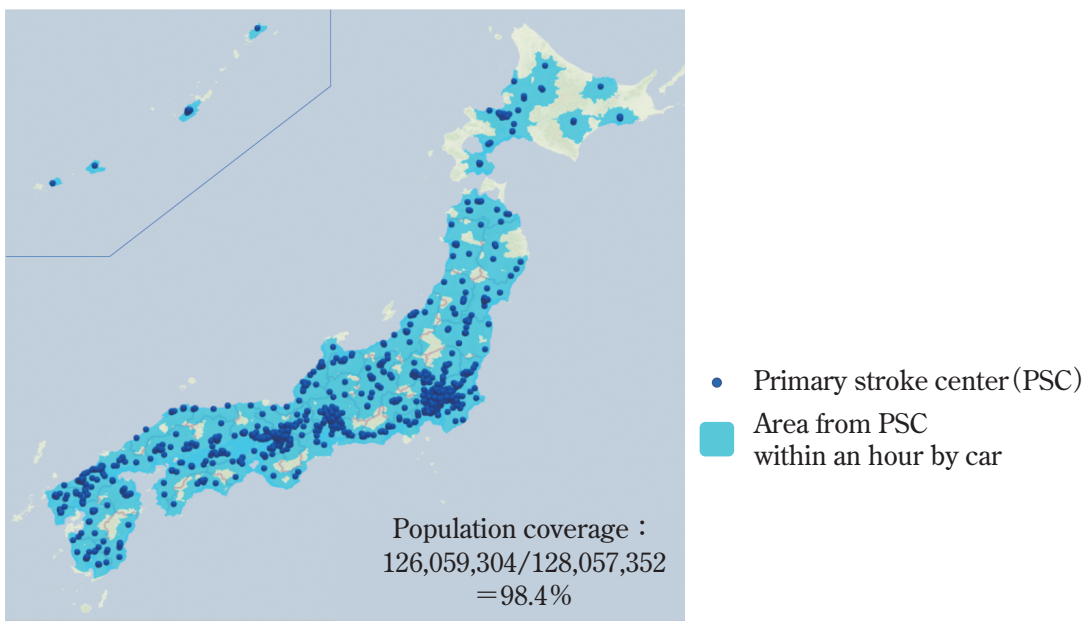

Fig. 2 Prevalence of primary stroke center (PSC) and the area from PSC within an hour by car

本計画に基づき，各都道府県において循環器病対策推進 協議会が設置され，地域事情に合わせた各都道府県の循 環器病対策推進基本計画が策定される見込みとなってい る. 日本脳卒中学会では都道府県における対策推進計画 について臨床現場に即した提言をアカデミアの立場から できるように，各都道府県に脳卒中対策推進委員会を設 置し, 同委員会は日本循環器学会が同様に設置した循環 器対策推進委員会と連携していく予定である。循環器病 対策基本法が施行されたことにより,「脳卒中と循環器 病克服 5 力年計画」と「循環器病対策推進計画」が車の 両輪のようになって脳卒中の診療体制の整備を進めるこ とになる。

循環器病対策基本法の第二条には，「保健，医療及び福 祉に係るサービスの提供が，その居住する地域にかかわ らず等しく, 継続的かつ総合的に行われるようにするこ と」と記載されているため, PSC の認定にあたつては, rt-PA 治療の均てん化を目標とすることになった，各都 道府県の脳卒中対策推進委員会によって二次医療圈ごと の精緻なシミュレーションが行われ，二次医療圈は $\mathrm{rt}^{-}$ PA 治療の提供体制によって (1)PSC が認定できる二次医 療圈と(2)PSC の認定が困難な二次医療圈に分類でき，後 者についてはすでに第 7 次医療計画で複数県において実 施されていた二次医療圈の合圈などによる脳卒中医療圈 としての対応，あるいは隣接医療圈にある PSC との連携 （PSC ネットワーク）で対応することになった，PSCネッ トワークとはネットワークを形成する病院群として 24 時間 365 日の対応が可能なものとした.

2019 年 10 月および 2020 年 3 月の 2 回にわたつて初年 度の認定作業が行わ机, 合計 975 施設の PSC と 6 つの
PSC ネットワークが認定された。この結果 PSC ネット ワークを含めると，島嶼（東京都）を除くすべての二次 医療圈において PSC 機能がある程度均てん化されたこ とを示している.Fig. 2 はPSCの分布と PSC から自動車 で 1 時間以内に移動可能な地域を示しており，人口カ バー率は $98.4 \%$ となっている。つまり，日本脳卒中学会 による PSC の認定は, 結果的に rt-PA 静注療法提供のビ ジネスモデルを医療圈ごとの事情に合わせて提言し，同 療法の均てん化達成状況を「見える化」したというアウ トプットをもたらしたことになる。

日本脳卒中学会が認定した PSC は「機械的血栓回収療 法が実施できることが望ましい。実施できない場合に は，機械的血栓回収療法が常時可能な近隣の一次脳卒中 センターとの間で，機械的血栓回収療法の適応となる患 者の緊急転送に関する手順書を有する」ことが要件と なっており，すべての PSC において機械的血栓回収療法 が可能というわけではない。 また，2019年の時点におい ては，その実施医である日本脳神経血管内治療学会の専 門医数が必ずしも十分ではなく，一部の専門医の過重労 働によって機械的血栓回収療法が実施されている施設あ るいは医療圈が存在していた。一方，同時並行している 「医師に対する㗢き方改革」の観点からすれば，機械的血 栓回収療法を 24/7 で提供するには，治療を実施する医 師が少なくとも 3 名以上在籍する必要があることは自明 であった。

日本脳卒中学会では機械的血栓回収療法の診療体制に ついて認定した PSC を対象として調査するとともに，各 都道府県の脳卒中対策推進委員会によって医療圈におけ る同療法提供体制の現状を調査した。その結果，二次医 
療圈別の機械的血栓回収療法の実施体制は以下の 4 類型 に分類された。

(1)機械的血栓回収療法を実施できる常勤の専門医が 3 名以上在籍し, 同療法を $24 / 7$ で提供できる PSC が存在 する二次医療圈

(2)労務上の負担が重い状況で，2 名以下の専門医が同 療法を $24 / 7$ で提供している PSC が存在する二次医療圈

(3)単一施設として $24 / 7$ を実施しているPSC はないが, 輪番などのネットワークで，同療法が $24 / 7$ で実施され ている二次医療圈

(4)患者転送や実施医の移動など医療圈外とのネット ワークで同療法を実施している二次医療圈

日本脳卒中学会, 日本脳神経外科学会, 日本脳神経血 管内治療学会が共同で策定した「経皮経管的脳血栓回収 機器 適正使用指針 第 3 版 (2018 年 3 月)」では機械的 血栓回収療法は，脳血管内治療専門医または同専門医に 準じる経験を有する医師が実施することとされていた が，「同専門医に準じる経験を有する医師」を明確にする ために，2020 年 4 月に同指針が改訂され，同年 8 月に脳 血栓回収療法実施医として認定されることとなった ${ }^{4)}$. これに伴い，機械的血栓回収療法は脳血管内治療専門医 と新たに設けられた脳血栓回収療法実施医によって実施 される体制が整った。この結果，機械的血栓回収療法を 担当する実施医が 3 名以上在籍する PSC はほぼすべての 三次医療圈に存在することとなった。日本脳卒中学会は このような施設を地域においてコアとなる PSC（以下 $「 \mathrm{PSC}$ コア施設」）とみなし, 各都道府県の脳卒中対策推 進委員会と密接な連携のもとに，先に示した二次医療圈 別の機械的血栓回収療法の実施状況を参考に，同療法の 均てん化に向けて今後努めるよう委嘱する予定である。

第 8 次医療計画は 2024 年度から開始される予定であ り，それに合わせて第 1 期循環器病対策推進計画は 2023 年度までとし, 第 2 期計画を第 8 次医療計画に連動させ て始めることが想定されている。この 2024 年は働き方 改革において医師の時間外労働の上限についての法的規 制が適用される年度であり，機械的血栓回収療法の提供 体制もこれに向けて整備していく必要がある.

一方，すべての医療が均てん化できるわけではなく， 高度医療については集約が必要である。高度医療を提供 するには，それに必要な機器整備とマンパワーの投入が 求められる。医療資源の乏しい地域や人口過疎地域にお いて, 医療資源が豊富な都市部と同様の整備は難しい.

脳卒中と循環器病克服 5 力年計画の「予防・国民への 啓発」を進めるプロジェクトチームでは，医療経済学的 な検証を行っており，機械的血栓回収療法を行うアンギ
才装置を購入し, 24/7 治療が可能な人的リソースを確保 して, 病院経営が成り立つためには, どれくらいの治療 件数が必要かを検証しており, 近日公表予定である.

疾患の発生数は背景人口にほぼ比例すると考えられ， 機械的血栓回収療法を常時提供可能な施設を設置可能な 医療圈人口の間值が示されることになる。その間值未満 の背景人口である医療圈においては医療施設側単独の努 力では経営は成り立たず，派遣されている専門医のモチ ベーションや技術水準の担保も難しい．とり得るべき対 策は遠隔医療や医療圈外一の患者搬送手段の整備，公的 支援など行政側の課題となることが可視化されるものと 思われる。

\section{登録事業の促進}

本邦において脳卒中対策を行ううえで疾患発生数など 悉皆性がある疫学的デー夕がないことがこれまでの大き な問題であった。

日本脳卒中学会は 2019 年から学会認定教育研修病院 （806 施設）の年次報告を義務化し，2020 年からは PSC からも年次報告が行わ机るようになった。いずれも前年 $1 \sim 12$ 月の当該施設における人的および設備要件の整備 状況や疾患別症例数や治療件数が報告されるようにな り, 患者個別のデー夕はないものの, 疫学的動態の経年 的把握が初めて可能となった。また，2019年からは学会 のプロジェクトチームとして厚労科研費研究事業に応募 し, 救急医療機関に対する悉皆調査で $\mathrm{rt}-\mathrm{PA}$ 治療件数や 急性期施設間連携の実態が把握できるようになった。こ れらのデータの突合により, 今後は PSC 年次報告をもと に, 全国はもとょり二次医療圈別の脳卒中疾患別発生数 や各治療の件数などの悉皆性がある疫学的デー夕を集め る体制が構築された。

一方, 循環器病対策基本法に基づき, 脳卒中患者の登 録事業が始まろうとしている。現在は厚労省が研究班を 設置し，ぞのように登録を行っていくかについての検討 が行わ机ている。まずは施設数を限ったモデル事業とし て顕名の登録が行わ机ていく見込みである。ただし，脳 卒中はがんのように登録に関する法的根拠がないこと， 脳卒中はがんのように治療施設が集約化されているわけ ではないという特徵がある。診療情報管理士の雇用財源 など，経済的な基盤がないままでは悉皆性のある登録事 業を推進するにはまだ多くのハードルがあると思われ， 現場の負担を軽減するためには IT の活用が不可欠であ る. 


\section{おわりに}

2016 年 12 月に公表された「脳卒中と循環器病克服 5 力年計画」は, 現在 5 年目を迎えており, その総括とそ れに続く第 2 期 5 力年計画の作成作業が行われている. 第 2 期 5 力年計画は 2021 年 3 月に公表される予定であ る.

第 1 期の脳卒中と循環器病克服 5 力年計画では，日本 脳卒中学会は医療体制の整備と登録事業の促進に傾注 し, 急性期医療の均てん化（PSC 認定）と学会登録事業 の開始という主に急性期に基軸をおいた整備が達成され た。

第 2 期の脳卒中と循環器病克服 5 力年計画では循環器 病対策推進計画と連動し, 回復期以後の慢性期にも基軸 を置いた整備が進むものと思われる。

\section{COI 状態}

著者全員は日本脳神経外科学会への COI 自己申告の登録を 完了しています。

本論文に関して開示すべき COI はありません。

\section{文 献}

1) Nakayama $H$, Minematsu K, Yamaguchi T, Miyamoto $S$, Isobe M, Komuro I, Yazaki Y: Approval of Stroke and Cardiovascular Disease Control Act in Japan. Comprehensive nationwide approach for prevention, treatment, and patients' support. Int J Stroke $\mathbf{1 5}: 7-8,2020$.

2) 日本脳卒中学会, 日本循環器学会, 日本胸部外科学会, 日本血管外科学会, 日本高血圧学会, 日本小児循環器学 会, 日本心エコー図学会, 日本心血管インターベンショ ン治療学会, 日本心臓血管外科学会, 日本心臓病学会, 日本心臟リハビリテーション学会, 日本心不全学会, 日 本成人先天性心疾患学会, 日本動脈硬化学会, 日本糖尿 病学会，日本脳神経血管内治療学会，日本脳神経外科学 会, 日本脳卒中の外科学会, 日本不整脈心電学会, 日本 脈管学会, 日本リハビリテーション医学会：脳卒中と循 環器病克服 5 力年計画一ストップ CVD (脳心血管病) 健 康長寿を達成するために一. http://www.j-circ.or.jp/five_ year/files/five_year_plan.pdf（閲覧 2020 年 9 月）

3）日本脳卒中学会脳卒中センター認定委員会：一次脳卒中 センター（PSC）認定について. https://www.jsts.gr.jp/ facility/psc/index.html（閲覧 2020 年 9 月）

4）日本脳卒中学会, 日本脳神経外科学会, 日本脳神経血管 内治療学会：経皮経管的脳血栓回収用機器 適正使用指 針 第 4 版. 脳卒中 $42: 281-313,2020$.

機械的血栓回収療法の発展とともに脳卒中の診療体制は大きく变貌を遂げつつある. 2016 年に発 表された「脳卒中と循環器病克服 5 力年計画」に基づき日本脳卒中学会は rt-PA 静注療法を均てん化 すべく 24 時間 365 日施行可能な 1 次脳卒中センターを全国で 975 施設認定した. 今後は 5 力年計画 と循環器病対策推進計画が連動し, primary care の均てん化と高度医療の集約化が進むものと思われ る. 